\title{
Consumer preference for locally grown produce: An analysis of willingness-to-pay and geographic scale
}

\author{
Perry Burnett, ${ }^{a}$ Todd H. Kuethe, ${ }^{\mathrm{b}}$ and Curtis Price
}

Submitted 10 March 2011 / Accepted 1 July 2011 / Published online 30 November 2011

Citation: Burnett, P., Kuethe, T. H., \& Price, C. (2011). Consumer preference for locally grown produce: An analysis of willingness-to-pay and geographic scale. Journal of Agriculture, Food Systems, and Community Development, 2(1), 269-278.

http://dx.doi.org/10.5304/jafscd.2011.021.013

Copyright (C) 2011 by New Leaf Associates, Inc.

\begin{abstract}
This study examines consumers' willingness-to-pay for locally grown fresh produce under five definitions of "local," including a generic term "locally grown" and four geographic intervals: multistate, state, regional, and county. A survey of 482 area residents in Evansville, Indiana, was conducted to examine how estimated price premiums vary with
\end{abstract}

\footnotetext{
${ }^{a}$ Corresponding author: University of Southern Indiana, 8600 University Boulevard, Evansville, IN 47712 USA; +1-812-465-7034; paburnett@usi.edu

b United States Department of Agriculture Economic Research Service, 355 E Street SW, Washington, DC 20472 USA; +1-202-694-5593; tkuethe@,ers.usda.gov

c University of Southern Indiana, 8600 University Boulevard, Evansville, IN 47712 USA; +1-812-461-5348; cprice1@usi.edu
}

\section{Disclosures}

The views expressed are those of the authors and should not be attributed to ERS or USDA. The survey was funded by the Department of Metropolitan Development in Evansville, Indiana. geographic scale. The results suggest that as the geographical scale shrinks, the estimated price premium increases. However, the differences across geographic intervals may not be substantial. Therefore, producers may expect similar price premiums when sourcing from larger geographic areas, and local food systems may ensure consistent profit margins while minimizing the costs of acquiring "local" foods.

\section{Keywords}

fresh produce, local foods, willingness-to-pay

\section{Introduction and Literature Review}

As Congress prepares the 2012 Farm Act, food and health issues are expected to be at the forefront of policy discussions. One area which has received increased attention is the rise of the local foods movement. The local foods movement is the result of several public concerns related to the agricultural sector, including environmental issues stemming from the geographic dimensions of food distribution, community food security, perceptions of large agricultural corporations, a better under- 
standing of the origin of food, and support for local farmers (Guptill \& Wilkins, 2002). In recent years, the movement has been the focus of bestselling books, newspaper and magazine articles, television news stories, and federal law and regulations (Hand \& Martinez, 2010).

The existing literature provides several examples of the economic benefits of local food systems. Farmers have the capacity to retain a greater share of the retail purchase price of food items (Darby, Batte, Ernst, \& Roe, 2008; Starr et al., 2003; Zepeda \& Li, 2006). Local food systems may lead to growth in local labor markets (Roininen, Arvola, \& Lahteenmaki, 2006) and increased business for nearby establishments (Lev, Brewer, \& Stephenson, 2003). In addition, Conner, Knudson, Hamm, and Peterson (2008) and Swenson (2009) demonstrate that local food systems can improve local economies through import substitution. That is, local consumers increase the consumption of locally produced items relative to those "imported" from outside the area, thereby increasing local income by retaining local spending. As a result, local food systems are often lauded as an important development strategy in rural areas (Ikerd, 2005; Marsden, Banks, \& Bristow, 2000; Ross, Anderson, Goldberg, Houser, \& Rogers, 1999).

Proponents of the movement suggest that local foods are also associated with many health benefits, and that local foods may be fresher, less processed, and retain more nutrients. Moore, Diez Roux, Nettleton, and Jacobs (2008) and Morland, Wing, and Roux (2002), therefore, suggest that local foods may lead to healthier dietary choices. The health benefits may also extend to improved community health outcomes (Bagdonis, Hinrichs, \& Schafft, 2009; Conner \& Levine, 2007; Lea, Phillips, Ward, \& Worsley, 2006; Vogt \& Kaiser, 2008).

While local food systems can improve local economies and provide health benefits, there is little consensus on the definition of "local" as it relates to the local food movement (Hand \& Martinez, 2010). The 2008 Farm Act (formally the Food, Conservation, and Energy Act of 2008) defines a locally produced agricultural food product as one that is transported less than 400 miles (644 kilometers) from its origin or that remains within the state in which it was produced. However, the term more generally implies food sourced from nearby farms and producers (Hand, 2010). Durham, King, and Roheim (2009) suggest that consumers exhibit variation in what they consider "local." In a survey of both producers and consumers in Washington state, Selfa and Quazi (2005) found significant variability in respondents' definition of "local." The authors therefore conclude, "this variability suggests that we, as researchers, need to continue to refine our investigations and our methodologies in order to uncover the nuances in meaning and purpose in the constructions of 'local' food systems”' (p. 462).

Given that "local" may carry different meanings to different consumers, this study examines consumers' willingness-to-pay (WTP) for locally grown, fresh produce under four alternative geographic definitions, as well as a generic "grown locally" designation. Martinez et al. (2010) note that one of the major challenges in designing a local food system is estimating the amount that consumers would be willing to pay for local products. The estimated price premiums may be helpful in costbenefit analyses of proposed expansions of local food systems. Previous studies have demonstrated that the costs of direct marketing can present obstacles to expanding local food sales (for example, Biermacher, Upson, Miller, \& Pitman, 2007). Varying the geographic intervals can help identify whether the costs of sourcing food items at a small geographic scale are met by consumers' potential price premiums.

In a comprehensive review of the local foods literature, Martinez et al. (2010) noted that identifying consumers' WTP for locally produced foods is useful in marketing local foods, and cites a number of studies that have examined the price premiums for local foods. The demand for locally grown fresh produce has been previously examined in a number of areas, such as Tennessee (Brooker \& Eastwood, 1989), Missouri (Brown, 2003), Delaware (Gallons, Toensmeyer, Bacon, \& German 
Figure 1. Study Area

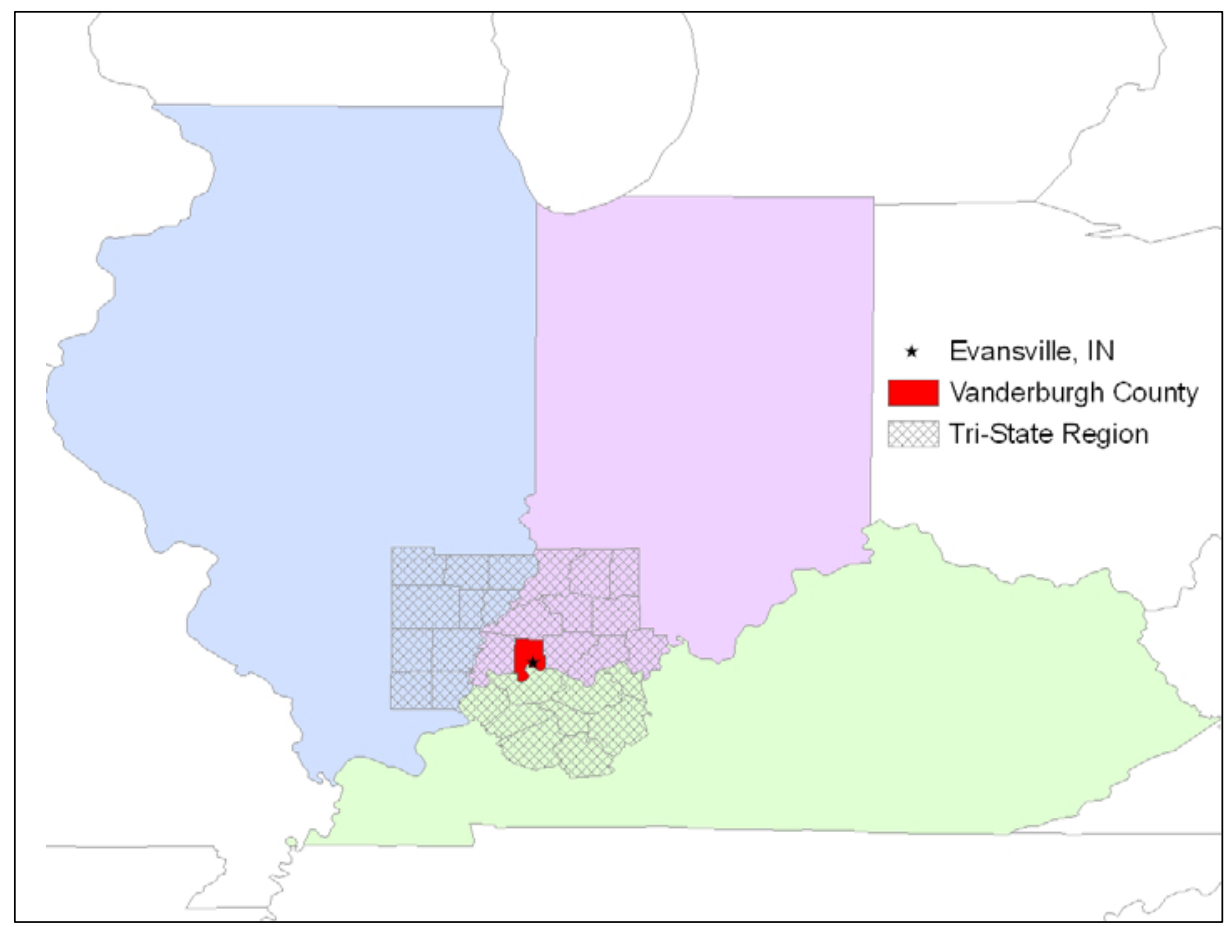

used extensively to elicit WTP, it has shortcomings. These include elicitation effects presumably due to the method's hypothetical nature, though Champ and Bishop (2006) also find elicitation effects when individuals make real donations. Boyle and Bishop (1988) find that respondent valuation can be influenced by the interviewer, while Kahneman and Knetsch (1992) argue that contingent valuation methods elicit moral satisfaction instead of economic value. While subject to these and other shortcomings, the compre-

hensive literature review by Martinez et al. (2010) demonstrates that contingent valuation is an accepted and widely adopted approach for empirical analysis of local food demand.

The survey instrument was designed to collect consumers' WTP for locally grown fresh produce at different geographic intervals. The geographic intervals used in the survey are the multistate level, state level, multicounty level, and county level. A premium for food items produced in-state has been demonstrated by Giraud, Bond, and Bond (2005). Schneider and Francis (2005) demonstrate a price premium for food produced in-county. Specifically, our survey used the following intervals: the Midwest, Indiana, the Tri-State, and Vanderburgh County, Indiana. The Tri-State is a $30-$ county region at the Illinois-Indiana-Kentucky intersection consisting of 10 Illinois counties, 11 Indiana counties, and nine Kentucky counties. The term is commonly used in local media and by local residents. Figure 1 shows the study area including

to various shortcomings, but are generally less costly and easier to implement. 
the city in which the survey was administered, Evansville, Indiana, as indicated by the black star. The city is located in Vanderburgh County, shown in red. Finally, the 30 county Tri-State region is shown in a grey cross-hash pattern. These geographic intervals were chosen over numerical intervals, such as mileage figures, to help inform policies regarding the promotion and marketing of local food systems.

Our survey was administered using the intercept method in Evansville, Indiana, the principal city of Vanderburgh County, Indiana, in November 2010. Surveys were conducted at locations and events that attracted residents from throughout the region, including the downtown museum and prior to the local holiday parade. This approach was successful in attracting respondents from 42 unique zip codes, with $63.6 \%$ of respondents residing in Vanderburgh County, $17.6 \%$ residing outside Vanderburgh County but within the TriState, and $18.7 \%$ not willing to identify their zip code. A total of 482 surveys were collected, resulting in an estimated response rate of $40 \% .^{3}$

The sociodemographic composition of the survey is comparable to the 2005-2009 American Community Survey data for the Evansville MSA as seen in table 1 . The percentage of female respondents to the present survey was $56.6 \%$, compared with $52.9 \%$ for the American Community Survey. The percent of respondents making between US $\$ 25,000$ and US $\$ 99,000$ annually was $53.7 \%$ in the current survey, compared with $56.8 \%$ for the American Community Survey. Other demographic data was collected, including the presence of children in the household, age group, education level, total household income, and travel time to the food market that the subject visits most often.

While the sample is not truly random, the demographics of the respondents are similar in a number of respects to the published demographics

${ }^{3}$ The response rate was estimated from postcollection interviews with the survey collectors, who estimated the percentage of persons who accepted out of the total asked to participate. of the region. The comparison suggests that while there was a similar age and percent female participation, our respondents were more educated, wealthier, and more likely to have children than the MSA as a whole. We believe this is likely due to the particular locations and events during which the data was collected. The literature suggests that this is a common shortcoming of the intercept surveying method (McGraw, McKinlay, Crawford, Costa, \& Cohen, 1992; Word, 1992).

\section{Table 1. Demographic Variables}

\begin{tabular}{|c|c|c|}
\hline Variable and Definition & Respondents & $\begin{array}{c}2005-2009 \\
\text { American } \\
\text { Community } \\
\text { Survey }\end{array}$ \\
\hline \multicolumn{3}{|l|}{ Gender } \\
\hline Female & $56.6 \%$ & $52.9 \%$ \\
\hline Male & $40.0 \%$ & $47.1 \%$ \\
\hline Prefer not to respond & $3.4 \%$ & $\mathrm{n} / \mathrm{a}$ \\
\hline \multicolumn{3}{|l|}{ Age (at least 15 years old } \\
\hline 15 to 24 & $22.0 \%$ & $18.5 \%$ \\
\hline 25 to 34 & $21.0 \%$ & $17.4 \%$ \\
\hline 35 to 44 & $20.8 \%$ & $20.1 \%$ \\
\hline 45 to 64 & $27.1 \%$ & $28.2 \%$ \\
\hline $65+$ & $9.1 \%$ & $15.8 \%$ \\
\hline Children in the household & $44.2 \%$ & $29.4 \%$ \\
\hline \multicolumn{3}{|l|}{ Income (all in US\$) } \\
\hline Less than $\$ 25,000$ & $19.9 \%$ & $35.4 \%$ \\
\hline$\$ 25,000$ to $\$ 40,000$ & $21.2 \%$ & $20.3 \%$ \\
\hline$\$ 41,000$ to $\$ 65,000$ & $19.0 \%$ & $20.6 \%$ \\
\hline$\$ 66,000$ to $\$ 99,000$ & $13.5 \%$ & $15.9 \%$ \\
\hline$\$ 100,000+$ & $13.7 \%$ & $7.8 \%$ \\
\hline Prefer not to respond & $12.7 \%$ & $\mathrm{n} / \mathrm{a}$ \\
\hline \multicolumn{3}{|l|}{ Education } \\
\hline High school or less & $26.0 \%$ & $51.6 \%$ \\
\hline Some college & $28.6 \%$ & $23.0 \%$ \\
\hline Associates degree & $11.1 \%$ & $7.6 \%$ \\
\hline BA/BS degree & $25.6 \%$ & $11.8 \%$ \\
\hline Graduate degree & $8.7 \%$ & $6.0 \%$ \\
\hline
\end{tabular}


Table 2. WTP category (all values in US\$ cents, where 100 cents $=1$ US $\$$ )

\begin{tabular}{cl}
\hline Qualitative Variable & Definition \\
\hline $\mathbf{0}$ & None \\
\hline $\mathbf{1}$ & $<5$ cents \\
\hline $\mathbf{2}$ & $5-9$ cents \\
\hline $\mathbf{3}$ & $10-14$ cents \\
\hline $\mathbf{4}$ & $15-19$ cents \\
\hline $\mathbf{5}$ & $>20$ cents \\
\hline
\end{tabular}

"grown in the Tri-State," and "grown in Vanderburgh County."

The premium, in cents per pound, was then qualitatively categorized on a rating scale ranging from 0 to $5 .{ }^{4}$ Table 2 shows the quantitative interpretation of each category. A higher category corresponds to a higher WTP for locally grown fresh produce.

The left column of table 3 provides a summary of the qualitative WTP responses. The mean WTP

Table 3. Willingness To Pay Summary

\begin{tabular}{|c|c|c|c|c|c|c|c|c|}
\hline \multirow[b]{2}{*}{ Category } & \multirow[b]{2}{*}{$\begin{array}{c}\text { \# of } \\
\text { Observations }\end{array}$} & \multirow[b]{2}{*}{ Mean } & \multicolumn{6}{|c|}{ p-values of two-sided t-tests } \\
\hline & & & $\begin{array}{l}\text { "Grown } \\
\text { Locally" }\end{array}$ & Midwest & Indiana & Tri-State & $\begin{array}{c}\text { Vanderburgh } \\
\text { County* }\end{array}$ & $\begin{array}{l}\text { Vanderburgh } \\
\text { County** }\end{array}$ \\
\hline "Grown Locally" & 465 & 2.00 & - & $<0.01$ & 0.33 & 0.86 & 0.28 & 0.21 \\
\hline Midwest & 465 & 1.67 & & - & 0.01 & $<0.01$ & $<0.01$ & $<0.01$ \\
\hline Indiana & 465 & 1.90 & & & - & 0.25 & 0.04 & 0.03 \\
\hline Tri-State & 463 & 2.01 & & & & - & 0.37 & 0.23 \\
\hline $\begin{array}{l}\text { Vanderburgh } \\
\text { County* }\end{array}$ & 459 & 2.10 & & & & & - & 0.70 \\
\hline $\begin{array}{l}\text { Vanderburgh } \\
\text { County**}\end{array}$ & 310 & 2.15 & & & & & & - \\
\hline
\end{tabular}

* Asked of all respondents; ** Asked of Vanderburgh County residents only

\section{Results}

Our survey instrument was designed to examine to what degree the price premium for locally sourced fresh produce varies by geographic interval. The survey instrument asked respondents to ponder the following scenario:

Assuming fresh produce was priced a $\$ 1.00$ per pound, how much of a premium would you be willing to pay (in cents per pound) for fresh produce containing each of the following characteristics?

The characteristics were divided into two parts. First, the respondent was asked the question in regards to the generic description, "grown locally." After the respondent responded, he or she was then presented with the four geographic intervals: "grown in the Midwest," "grown in Indiana," suggests that as the geographic interval for local production shrinks, the average price premium increases. Also of note is that the generic term "grown locally" appears most closely aligned to the Tri-State value, suggesting that the typical geographic interval related to "local" is the multicounty or regional level. Interestingly, the WTP at the Vanderburgh County level did not deviate significantly when the results from respondents residing inside the county were isolated.

\footnotetext{
4 The survey instrument used a rating scale that ranged from 1 to 6 in decreasing order of WTP, i.e., 1 represented a WTP of more than 20 cents per pound, 2 represented a WTP of 15-19 cents per pound, etc. For the purpose of the analysis we converted this to a more standard representation where the WTP increases with an increase in the categorical variable, using a scale of 0 to 5 .
} 
Figure 2. Willingness To Pay Results

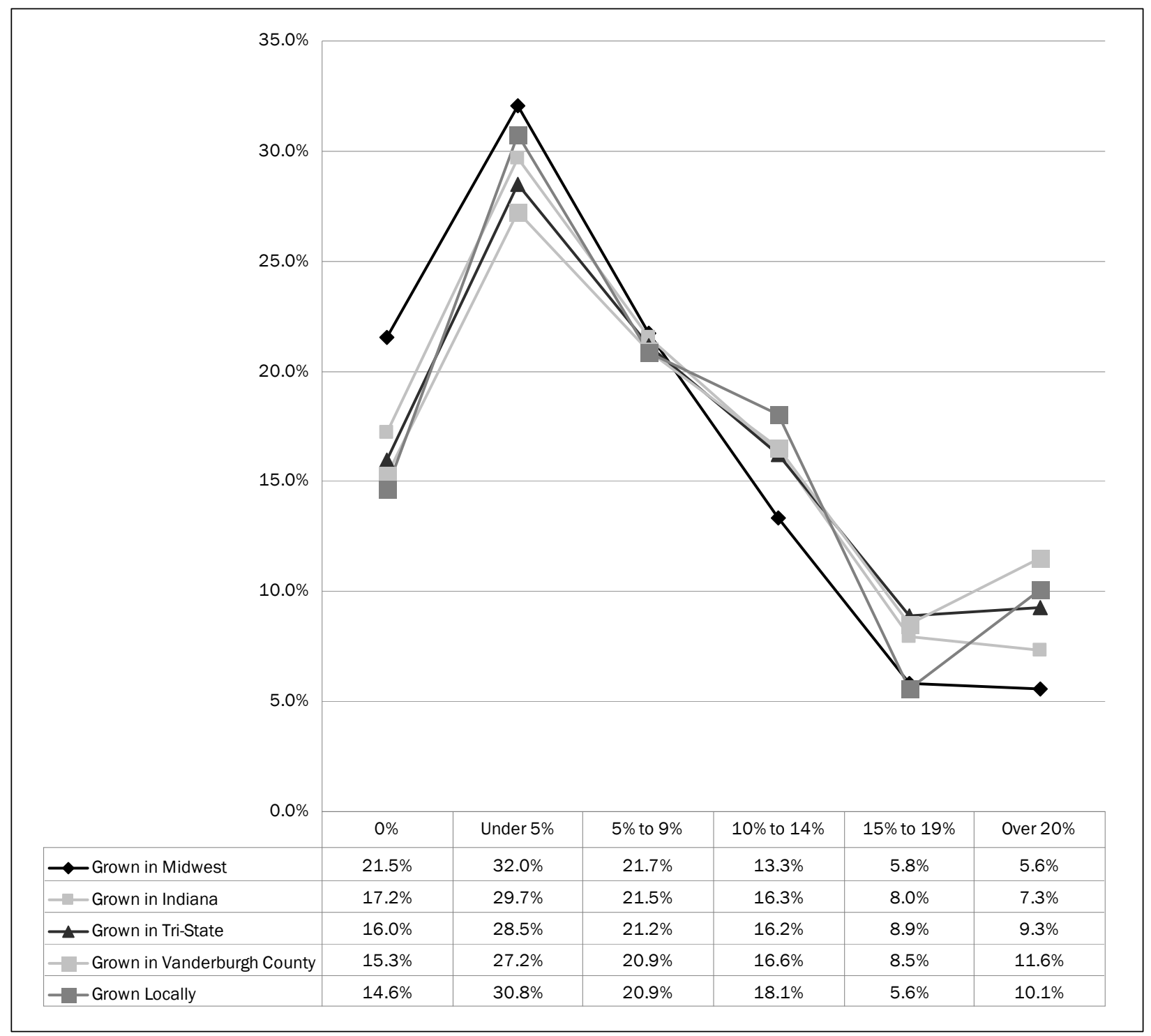

The right columns of table 3 show p-values of a ttest to measure the statistical difference in the mean across geographic intervals. Note that "Midwest" is significantly different from all other categories with a p-value of less than 0.05 . Additionally, the differences between "Indiana" and "Vanderburgh County" is statistically significant across all respondents $(\mathrm{p}$-value $=0.04)$ and when the respondents are limited to only Vanderburgh County residents $(\mathrm{p}$-value $=0.03) .{ }^{5}$

\footnotetext{
${ }^{5}$ Since the Vanderburgh County geographic interval is the only interval with well defined boundaries, we thought it would be prudent to show how the mean W'TP varies with respondents who live within Vanderburgh County. This is the last row in table 3 . To this end, we used zip codes, which were asked of the respondents, to identify Vanderburgh County residents. The zip codes used for Vanderburgh County, IN, are 47701-47750. All zip codes are within the border of Vanderburgh County except for 47725 (99.3\% of zip code is within county border) and 47712 (88.5\%). The zip codes
} 
geographic intervals, as well as the generic "grown locally" category. Roughly $15 \%$ to $20 \%$ of respondents do not express a price premium for local produce, and the modal response category (under $5 \phi$ premium) accounts for $27 \%$ to $32 \%$ of responses. The smallest geographic interval, "grown in Vanderburgh County," ranks highest in only the top WTP category, above $20 \notin$ premium.

In sum, the results suggest that WTP for locally grown fresh produce does not deviate substantially across the definitions of "local," though mean WTP increases as the geographic interval shrinks. Previous studies of local foods systems suggest that marketing costs can present obstacles to the expansion of local food sales (Biermacher et al., 2007). The transaction costs associated with securing locally produced food items at a consistent quality, particularly fresh produce, may also substantially limit the development of local food value chains. The survey results suggest that, although there is some expected price premium for tighter definitions of "local" foods, the price premiums do not vary substantially from large, multistate definitions (Midwest) to small political boundaries (Vanderburgh County). In other words, the costs associated with developing more geographically concentrated food systems, or "foodsheds" as termed by Kloppenburg, Hendrickson, and Stevenson (1996), may not be balanced by higher price premiums received. Instead, food distributors may expect similar premiums for "local" foods drawn from larger geographic areas.

\section{Conclusions}

The local foods movement is the expression of a number of food, environmental, and health concerns, including concerns about the environmental impacts of food distribution networks, a better understanding of food origins, and the financial support of local farmers. In recent years, the movement has been the subject of best-selling books, popular media stories, and public policy. One important component of developing local food systems is identifying consumers' WTP for

$47639(16.2 \%)$ and $47633(2.6 \%)$ are found in the county, but are not included. locally produced food products. A number of previous studies have shown that consumers are willing to pay a premium for "local" foods, including such food items as dairy (Best \& Wolfe, 2009), pork (Grannis \& Thilmany, 2002), and strawberries (Hinson \& Bruchhaus, 2005).

This study examines consumers' WTP for fresh produce using a survey of 482 area residents in Evansville, Indiana. The survey instrument was designed to test the differences in premiums based on five geographic definitions of "local" foods. As noted in the literature, there is not a consensus on what defines local foods (Martinez et al., 2010). We, therefore, elicit consumers' WTP for a generic "grown locally" designation, as well as four geographic intervals, including Midwest, Indiana, Tri-State Region, and Vanderburgh County (the location of Evansville, Indiana). Although a number of studies examine consumers' WTP for fresh produce, the relationship between price premiums and geographic scale have not been well studied.

Roughly $85 \%$ of respondents offered a positive WTP for fresh produce under the generic "grown locally" moniker. This percent increases as the geographic scale shrinks from Midwest $(78 \%)$ to county level $(85 \%)$. In addition, the mean price premium increases as the geographic interval shrinks. This suggests that consumers may place a higher premium on foods under tighter definitions of "local." However, examining the distribution of WTP for each definition, there does not appear to be a substantial variation in price premiums.

This new information may be useful for parties interested in developing local food marketing programs or establishing new food distribution infrastructure. For example, the survey results suggest that price premiums do not vary substantially when "local" is defined as a multistate region or county. However, the cost of sourcing locally grown fruits and vegetables from small geographic areas may be prohibitively expensive. Local food retailers, then, may expect similar revenues with substantially lower costs when marketing "local" foods from larger multistate regions. This 
potentially could improve the profitability of a local food system and ensure economic sustainability.

In addition, the discovery may be informative to new policies that address the local food movement. By better understanding consumers perceptions of "local," policy-makers will be able to improve efficiency of program benefits with respect to location. Given that consumers tolerate similar price premiums across the definitions of "local," effective policies can be designed that incorporate foods from a larger area in a more economically sustainable fashion.

This study examines price premium variations for different geographic definitions of "local," using a broad category of locally produced foods, namely, fresh produce. While this study found that consumers do not appear to exhibit substantial variation, the results of this study may not apply to each locally produced food. In other words, there may exist a substantial premium for specific locally produced foods. Therefore, future research is required regarding the degree to which this phenomenon holds true for specific food items.

\section{Acknowledgements}

We wish to thank the students of Labor Economics (Fall 2010) at University of Southern Indiana (USI) for their participation in survey focus groups and data collection. We also wish to thank Dr. Katherine A. Draughon, director of planning, research and assessment at USI, who was consulted during the development of the survey.

\section{References}

Bagdonis, J. M., Hinrichs, C. C., \& Schafft, K. A. (2009). The emergence and framing of farm to school initiatives: Civic engagement, health, and local agriculture. Agriculture and Human Values, 26, 107119. http://dx.doi.org/10.1007/s10460-008-9173-6

Best, M. J., \& Wolfe, K. L. (2009). A profile of local dairy consumers in the Southeast and the potential for dairies to market value-added products locally. Journal of Food Distribution Research, 40, 22-31.

Biermacher, J., Upson, S., Miller, D., \& Pitman, D. (2007). Economic challenges of small-scale vegetable production and retailing in rural communities: An example from rural Oklahoma. Journal of Food Distribution Research, 38(3), 1-13.

Boyle, K. J., \& Bishop, R. C. (1988). Welfare measurements using contingent valuation: A comparison of techniques. American Journal of Agricultural Economics, 70(1), 20-28. http://dx.doi.org/10.2307/1241972

Brooker, J. R., \& Eastwood, D. B. (1989). Using state logos to increase purchases of selected food products. Journal of Food Distribution Research, 20, 175-183.

Brown, C. (2003). Consumers' preferences for locally produced food: A study in southeast Missouri. American Journal of Alternative Agriculture, 18(4), 213224. http://dx.doi.org/10.1079/AJAA200353

Champ, P. A., \& Bishop, R. C. (2006). Is willingness to pay for a public good sensitive to the elicitation format? Land Economics, 82(2), 162-173.

Conner, D. S., Knudson, W. A., Hamm, M. W., \& Peterson, H. C. (2008). The food system as an economic driver: Strategies and applications for Michigan. Journal of Hunger and Environmental Nutrition, 3(4), 371-383. http://dx.doi.org/ $\underline{10.1080 / 19320240802528849}$

Conner, D. S., \& Levine, R. (2007). Circles of association: The connections of community-based food systems. Journal of Hunger and Environmental Nutrition, 1(3), 5-25. http://dx.doi.org/10.1300/J477v01n03_02

Darby, K., Batte, M. T., Ernst, S. , \& Roe, B. (2008). Decomposing local: A conjoint analysis of locally produced foods. American Journal of Agricultural Economics, 90(2), 476-486. http://dx.doi.org/ 10.1111/j.1467-8276.2007.01111.x

Durham, C. A., King, R. P. , \& Roheim, C. A. (2009). Consumer definitions of "locally grown" for fresh fruits and vegetables. Journal of Food Distribution Research, 40, 56-62.

Gallons, J., Toensmeyer, U. C., Bacon, J. R., \& German, C. L. (1997). An analysis of consumer characteristics concerning direct marketing of fresh produce in Delaware: A case study. Journal of Food Distribution Research, 28, 98-106.

Giraud, K. L., Bond, C. A., \& Bond, J. J. (2005, October). Consumer preferences for locally made specialty food products across Northern New England. Agricultural and Resource Economics Review, 34(2), 204-216. Available at http://purl.umn.edu/10231 
Grannis, J., \& Thilmany, D. (2002). Marketing natural pork: An empirical analysis of consumers in the Mountain Region. Agribusiness, 18(4), 475-489. http://dx.doi.org/10.1002/agr.10029

Guptill, A., \& Wilkins, J. L. (2002). Buying into the food system: Trends in food retailing in the US and implications for local foods. Agriculture and Human Values, 19(1), 39-51. http://dx.doi.org/ 10.1023/A:1015024827047

Hand, M. (2010, December). Local food supply chains use diverse business models to satisfy demand. Amber Waves. Available at http://www.ers.usda. gov/AmberWaves/December10/Features/ SupplyChains.htm

Hand, M., \& Martinez, S. (2010). Just what does local mean? Choices, 25(1). Available at http://www.choicesmagazine.org

Hinson, R. A., \& Bruchhaus, M. N. (2005). Louisiana strawberries: Consumer preferences and retailer advertising. Journal of Food Distribution Research, 36(1), 86-90. Available at http://purl.umn.edu/26772

Ikerd, J. (2005). Eating local: A matter of integrity, presentation at The Eat Local Challenge kickoff event, Portland, Oregon, June 2, 2005.

Kahneman, D., \& Knetsch, J. L. (1992). Valuing public goods: The purchase of moral satisfaction. Journal of Environmental Economics and Management, 22, 57-70. http://dx.doi.org/10.1016/0095-0696(92)90019-S

Kloppenburg, J., Hendrickson, J., \& Stevenson, G. W. Coming in to the foodshed. Agriculture and Human Values, 13(3), 33-42. http://dx.doi.org/10.1007/ $\underline{\text { BF01538225 }}$

Lea, E., Phillips, J., Ward, M., \& Worsley, A. (2006). Farmers' and consumers beliefs about community supported agriculture in Australia: A qualitative approach. Ecology of Food and Nutrition, 45(2), 61-86. http://dx.doi.org/10.1080/03670240500530592

Lev, L., Brewer, L., \& Stephenson, G. (2003). How do farmers' markets affect neighborhood businesses? Oregon Small Farms Technical Report No. 16, Small Farms Extension Program, Oregon State University, Corvallis, Oregon.

Loureiro, M. L., \& Hine, S. (2002). Discovering niche markets: A comparison of consumer willingness to pay for local (Colorado grown), organic, and GMOfree products. Journal of Agricultural and Applied Economics, 34(3), 477-487.
Marsden, T., Banks, J., \& Bristow, G. (2000). Food supply chain approaches: Exploring their role in rural development. Sociologica Ruralis, 40, 424-438. http://dx.doi.org/10.1111/1467-9523.00158

Martinez, S., Hand, M., Da Pra, M., Pollack S., Ralston, K., Smith, T., Vogel, S., Clark, S., Lohr, L., Low, S., \& Newman, C. (2010). Local food systems: Concepts, impacts, and issues. Economic Research Report No. 97, United States Department of Agriculture Economic Research Service, Washington, D.C.

McGraw S. A., McKinlay, J. B., Crawford, S. A., Costa, L. A., \& Cohen, D. L. (1992). Health survey methods with minority populations: Some lessons from recent experience. In D. M. Becker, D. R. Hill, J. S. Jackson, D. M. Levine, F. A. Stillman, S. M. Weiss (Eds). Health behavior research in minority population: Access, design, and implementation (pp. 149_ 167). Washington, D.C.: National Institutes of Health.

Mitchell, R. C., \& Richard, C. T. (1981). An experiment in determining willingness to pay for national water quality improvements. Resources for the Future. Draft report to U.S. Environmental Protection Agency, Washington D.C.

Moore, L. V., Diez Roux, A. V., Nettleton, J. A., \& Jacobs, D. R. (2008). Associations of the local food environment with diet quality: A comparison of assessments based on surveys of geographic information systems. American Journal of Epidemiology, 167(8), 917-924. http://dx.doi.org/10.1093/ aje/kwm394

Morland, K., Wing, S., \& Roux, A.D. (2002). The contextual effect of the local food environment on residents' diets: 'The atherosclerosis risk in communities study. American Journal of Public Health, 92, 1761-1767.

Roininen, K., Arvola, A., \& Lahteenmaki, L. (2006). Exploring consumers' perceptions of local food with two different qualitative techniques: Laddering and word association. Food Quality and Preference, 17, 20-30. http://dx.doi.org/10.1016/i.foodqual. 2005.04.012

Ross, N. J., Anderson, M. D., Goldberg, J. P., Houser, R., \& Rogers, B. L. (1999). Trying and buying locally grown produce at the workplace: Results of marketing intervention. American Journal of Alternative Agriculture, 14, 171-179. http://dx.doi.org/10.1017/S0889189300008353 
Schneider, M. L., \& Francis, C. A. (2005). Marketing locally produced foods: Consumer and farmer opinions in Washington County, Nebraska. Renewable Agriculture and Food Systems, 20, 252-260. http://dx.doi.org/10.1079/RAF2005114

Selfa, T., \& Quazi, J. (2005). Place, taste, or face-to-face? Understanding producer-consumer networks in "local" food systems in Washington State. Agriculture and Human Values, 22, 451-464. http://dx.doi.org/10.1007/s10460-005-3401-0

Starr, A., Card, A., Benepe, C., Auld, G., Lamm, D., Smith, K., \& Wilken, K. (2003). Sustaining local agriculture: Barriers and opportunities to direct marketing between farms and restaurants in Colorado. Agriculture and Human Values, 20, 301321. http://dx.doi.org/10.1023/A:1026169122326

Swenson, D. (2009). Investigating the Potential Economic Impacts of Local Foods for Southeast Iowa. Leopold Center for Sustainable Agriculture. Ames, IA
Vogt, R. A., \& Kaiser, L. L. (2008). Still a time to act: A review of institutional marketing of regionallygrown food. Agriculture and Human Values, 25, 241255. http://dx.doi.org/10.1007/s10460-007-9106-9

Wolf, M. M. (1997). A target consumer profile and positioning for promotion of the direct marketing of fresh produce: A case study. Journal of Food Distribution Research, 28, 11-17.

Word, C. O. (1992). Cross-cultural methods for survey research in black urban areas. In A. K. H. Burlew, W. C. Banks, H. P. McAdoo, \& D. A. Azibo (Eds.). African American psychology (pp. 28-42). Newbury Park, California: Sage Publications.

Wolf, M. M., Spittler, A., \& Ahern, J. (2005). A profile of farmers' market consumers and the perceived advantages of produce sold at farmers' markets. Journal of Food Distribution Research, 36, 192-201.

Zepeda, L., \& Li, J. (2006). Who buys local food? Journal of Food Distribution Research, 37, 1-11. 